Jurnal Keperawatan Silampari

Volume 4, Nomor 2, Juni 2021

e-ISSN: 2581-1975

p-ISSN: $2597-7482$

DOI: https://doi.org/10.31539/jks.v4i2.2120

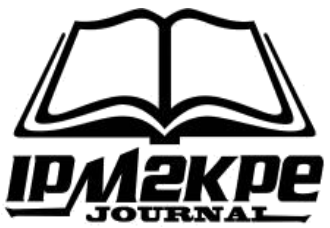

\title{
THERAPY BRAIN GYM TERHADAP SHORT MEMORY ANAK RETARDASI MENTAL
}

\author{
Panzilion $^{1}$, Juli Andri ${ }^{2}$, Padila ${ }^{3}$ \\ Universitas Muhammadiyah Bengkulu ${ }^{1,2,3}$ \\ panzilion@umb.ac.id ${ }^{1}$
}

\begin{abstract}
ABSTRAK
Penelitian ini bertujuan untuk mengetahui pengaruh therapy brain gym terhadap peningkatan short memory anak retardasi mental usia sekolah. Jenis penelitian ini adalah penelitian kuantitatif dengan rancangan quasy eksperimen, one groups pre and post test design. Hasil penelitian didapatkan nilai t-dependen pre-post test brain gym, dengan p-value 0,000 dan nilai mean pada anak yang diberikan intervensi brain gym 10,60 dengan standar deviasi 0.996. Simpulan, adanya pengaruh therapy brain gym terhadap peningkatan short memory anak usia sekolah di Sekolah Dasar Luar Biasa Negeri 05 Kota Bengkulu.
\end{abstract}

Kata Kunci: Brain Gym, Retardasi Mental, Short Memory, Usia Sekolah

\section{ABSTRACT}

This study aims to determine the effect of brain gym therapy on increasing short memory of school-age mentally retarded children. This type of research is a quantitative study with a quasi-experimental design, one groups pre and post test design. The results showed that the tdependent value of the brain gym pre-post test, with a p-value of 0.000 and the mean value for children who were given brain gym intervention was 10.60 with a standard deviation of 0.996. In conclusion, there is an effect of brain gym therapy on increasing short memory of school-age children at State Elementary School 05 Bengkulu City.

Keywords: Brain Gym, Mental Retardation, Short Memory, School Age

\section{PENDAHULUAN}

Anak dengan Retardasi Mental (RM) mempunyai keterlambatan dan keterbatasan dalam semua area perkembangan sehingga mereka mengalami kesulitan untuk memiliki kemampuan dalam merawat diri sendiri dan cenderung memiliki ketergantungan dengan lingkungan terutama pada orang tua dan saudaranya (Dewi, 2017; Padila et al., 2021; Panzilion et al., 2021). World Health Organization (2019) memperkirakan bahwa lebih dari 450 juta anak mengalami gangguan mental atau tunagrahita di dunia. Retardasi mental menjadi beban penyakit tersendiri di dunia sebesar $12 \%$ dan diperkirakan meningkat $15 \%$ pada tahun 2020 . 
Pravelensi penduduk Indonesia dengan disabilitas mental sedang dan berat berdasarkan hasil Riskesdas (2018) menunjukkan proporsi disabilitas pada usia 5-17 tahun sebesar 3,3\%. Proporsi disabilitas pada anak usia 5- 17 tahun berdasarkan provinsi tertinggi ditempati oleh Sulawesi Tengah dengan angka $7 \%$, dan terendah ditempati oleh Sulawesi Barat dengan angka 1,4 \%. Menurut Data Dinas Kesehatan Provinsi Bengkulu (2019) penyandang cacat dari usia 0-17 tahun adalah 1732 anak, dengan anak yang mengalami retardasi mental sebanyak 533 anak atau $31.93 \%$.

Short memory atau memori jangka pendek berperan besar dalam aspek perkembangan kognitif sehingga memberikan pengaruh terhadap intelegensia dan prestasi akademik anak. Setiap kejadian yang dialami oleh seseorang dalam beberapa menit pasca kejadian akan tersimpan dalam memori jangka pendek. Memori jangka pendek ini berperan dalam pemecahan masalah yang posisinya berada dalam pikiran sadar. Kecepatan proses kognitif diketahui bergantung dari derajat aktivasi memori jangka pendek (Padila et al., 2019; Wulansari, 2018). Menurut Marpaung et al., (2017) memori jangka pendek mempunyai peranan dalam pikiran sadar. Memori ini lebih sering digunakan untuk menyimpan bagianbagian kegiatan yang telah dilakukan serta mencerna informasi yang diterima.

Anak RM mengalami kesulitan dalam hal mengingat, maka dari itu dibutuhkan terapi terapi yang dapat merangsang daya ingat anak. Salah satu terapi untuk merangsang daya ingat anak adalah brain gym, terapi ini berfungsi untuk merangsang daya ingat dimana terdapat gerakan-gerakan yang berfungsi untuk merangsang pusat perhatian anak. Menurut Martini et al., (2016) untuk memudahkan peserta didik dalam kegiatan belajar maka dibutuhkan stimulus gerakan yang mampu menyeimbangkan otak dan melatih kefokusan anak, Senam otak merupakan salah satu solusi yang tepat dalam masalah tersebut. Selain itu, senam otak juga meningkatkan kemampuan berbahasa dan daya ingat serta mampu mengkordinasikan semua gerakan ektremitas atas terutama motorik halus (Panzilion et al., 2020).

Pratiwi et al., (2016) mengatakan bahwa brain gym atau senam otak merupakan serangkaian latihan gerak sederhana untuk meningkatkan kemampuan belajar peserta didik dengan menggunakan otak secara keseluruhan. Gerakan-gerakan dalam senam otak memiliki banyak manfaat. Senam otak membuat siswa lebih mudah dalam menerima segala macam pelajaran dan dapat memahaminya dengan baik, serta memiliki banyak manfaat bagi kemampuan akademik siswa (Panzilion et al., 2020).

Didukung oleh penelitian Prasetyo \& Saputra (2017) yang menyatakan bahwa daya ingat siswa kelas $\mathrm{V}$ sebelum dilakukan terapi senam otak berada direntang nilai cukup $(50,00 \%)$, setelah terapi senam otak menjadi sangat baik $(45,83 \%)$. Gerakan-gerakan pada senam otak merupakan jembatan yang membentuk koneksi atau hubungan antara otak dan tubuh. Gerakan pada senam otak dapat mengaktifkan organ dan sistem pada tubuh manusia melalui kerja sistem saraf dengan membagi gerakan-gerakan pada tiga dimensi, yaitu dimensi lateralis, dimensi pemfokusan dan dimensi pemusatan. Dimensi-dimensi tersebut berkaitan dengan fungsi otak yang spesifik dan menggambarkan penggunaan otak secara menyeluruh dalam proses belajar. Pola tiga dimensi dalam senam otak bertujuan untuk menciptakan kongruensi dimana akses putaran cepat dan putaran lambat bisa terintegrasi pada tiga dimensi ini. Karena keadaan seimbang hanya bisa tercipta bila semua tiga dimensi bekerja secara konsisten (Padila et al., 2019). 
Berdasarkan hasil survey yang dilakukan pada tanggal Januari 2021, terdapat 48 siswa yang bersekolah di SDLBN 05 Kota Bengkulu. Dari jumlah siswa tersebut yang mengalami retardasi mental 21 siswa laki-laki dan 9 siswa perempuan, anak retardasi mental atau tunagrahita mengalami kesulitan dalam mengingat terkhusus dalam mengingat jangka pendek maka dibutuhkan intervensi yang tepat untuk meningkatkan short memory tersebut salah satu contoh adalah pemberian therapy brain gym.

Dari beberapa literature yang dijadikan sumber, therapy brain gym hanya dilakukan pada anak yang bersekolah ditempat umum saja namun dalam penelitian ini therapy brain gym dilaksanakan pada anak berkebutuhan khusus dengan retardasi mental.

\section{METODE PENELITIAN}

Jenis penelitian ini adalah penelitian kuantitatif dengan rancangan eksperimen, one group pre-post test yaitu dimana penelitian ini sempelnya diambil secara random sampling. Total sampel dalam penelitian ini ada 10 anak dengan kriteria inklusi yaitu anak yang bersekolah di SDLBN 05 Kota Bengkulu, riwayat retardasi mental, berada di kelas 5 dan 6, bersedia menjadi respoden, mengikuti intervensi brain gym sampai dengan selesai. Pelaksanaan penelitian dilakukan di SDLB No.5 Kota Bengkulu pada bulan Februari - Maret 2021 dengan 2 kali intervensi perminggu.

Sebelum pelaksanaan intervensi, anak RM di ukur terlebih dahulu short memorynya dan kemudian di berikan intervensi selama 45 menit selama 7 minggu dengan 14 kali intervensi, pada pertemuan ke 14 anak diukur short memory kembali menggunakan kuesioner digid forward.

\section{HASIL PENELITIAN} Analisis Univariat

Tabel.1

Distribusi Frekuensi Short Memory pada Anak Sekolah Sebelum Diberikan Therapy Brain Gym

\begin{tabular}{lcc}
\hline \multicolumn{1}{c}{ Short Memory } & Frekuensi & Persentase (\%) \\
(Post Play Therapy with Brain Gym) & & \\
\hline Baik & 3 & 70 \\
Kurang & 7 & 100 \\
\hline Total & 10 & 100 \\
\hline
\end{tabular}

Berdasarkan tabel 1 dapat diketahui bahwa dari 10 anak, terdapat 7 anak (70\%) dengan short memory kurang di SDLBN 05 Kota Bengkulu.

Tabel. 2

Distribusi Frekuensi Short Memory pada Anak Usia Sekolah

Setelah Diberikan Play Therapy With Brain Gym

\begin{tabular}{lcc}
\hline \multicolumn{1}{c}{ Short Memory } & Frekuensi & Persentase (\%) \\
(Post Play Therapy with Brain Gym) & & 90 \\
\hline Baik & 9 & 10 \\
Kurang & 1 & 100 \\
\hline Total & 10 & \\
\hline
\end{tabular}


Berdasarkan tabel 2 dapat diketahui bahwa dari 10 orang anak, 9 anak (90\%) dengan Short Memory baik di SDLBN 05 Kota Bengkulu.

\section{Analisis Bivariat}

Tabel. 3

Pengaruh peningkatan Short Memory Sebelum dan Sesudah

Diberikan Therapy Brain Gym pada Anak Usia Sekolah

\begin{tabular}{cccccc}
\hline Variabel & Mean & $\mathrm{N}$ & $\begin{array}{c}\text { Std. } \\
\text { Deviation }\end{array}$ & CI & $p$-value \\
\hline $\begin{array}{c}\text { Short Memory Pre Therapy Brain } \\
\text { Gym }\end{array}$ & 6.50 & & 1.080 & -3.063 & \\
\cline { 1 - 2 } $\begin{array}{c}\text { Short Memory Post Therapy Brain } \\
\text { Gym }\end{array}$ & 10.60 & & 0.966 & 5.137 & 0.000 \\
\hline
\end{tabular}

Berdasarkan tabel 3 diketahui bahwa sebelum dilakukan intervensi therapy brain gym didapatkan nilai mean (6.50) dengan standar deviasi (1.080) sedangkan sesudah diberikan intervensi didapatkan nilai mean (10.60) dengan standar deviasi $(0,966)$. nilai p sebelum dan sesudah dilakukan intervensi sebesar 0.000 yaitu lebih kecil dari p value 0.005 dengan demikian dapat disimpulkan bahwa terdapat pengaruh setelah diberikan intervensi therapy brain gym pada anak usia sekolah di SDLBN 05 Kota Bengkulu.

\section{PEMBAHASAN}

Analisi Univariat

Berdasarkan tabel 1 diketahui bahwa dari 10 anak, sebagian besar anak dengan short memory kurang di SDLBN 05 Kota Bengkulu. Hal tersebut selaras dengan hasil penelitian Wulansari (2018) yang menyatakan kecepatan proses kognitif pada anak RM bergantung dari derajat aktivasi memori jangka pendek dan stimulasi otak yang diberikan (Diana et al., 2017).

Dilihat dari tabel 2 dari hasil penelitian diketahui bahwa dari 10 responden, sebagian besar anak dengan short memory baik setelah diberikan terapi. Senam otak akan mengaktifkan mekanisme integrasi otak. Gerakan-gerakannya merupakan jembatan yang membentuk koneksi atau hubungan antara otak dan tubuh. Sehingga dapat mengaktifkan organ dan sistem pada tubuh manusia, melalui kerja sistem saraf dengan membagi gerakan-gerakan pada tiga dimensi, yaitu dimensi lateralis, dimensi pemfokusan dan dimensi pemusatan. Dimensidimensi tersebut berkaitan dengan fungsi otak yang spesifik dan menggambarkan penggunaan otak secara menyeluruh dalam proses belajar. Pola tiga dimensi dalam senam otak bertujuan untuk menciptakan kongruensi dimana akses putaran cepat dan putaran lambat bisa terintegrasi pada tiga dimensi ini. Karena keadaan seimbang hanya bisa tercipta bila semua tiga dimensi bekerja secara konsisten (Robot et al., 2019; Panzilion et al., 2021).

Pratiwi et al., (2016) mengatakan bahwa brain gym atau senam otak merupakan serangkaian latihan gerak sederhana untuk meningkatkan kemampuan belajar peserta didik dengan menggunakan otak secara keseluruhan. Gerakan-gerakan dalam senam otak memiliki banyak manfaat. Senam otak membuat siswa lebih mudah dalam menerima segala macam pelajaran dan dapat memahaminya dengan baik, serta memiliki banyak manfaat bagi kemampuan akademik siswa. 
Sejalan dengan penelitian Akbarjono et al., (2019) disimpulkan bahwa pengaruh brain gym dalam meningkatkan memori jangka pendek / short memory pada anak usia 8-9 mengalami peningkatan dari $78 \%$ meningkat menjadi $85,71 \%$ dan meningkat menjadi $92,85 \%$ pada kemampuan memori jangka pendek terlihat baik setelah diberikan senam otak.

\section{Analisi Bivariat}

Berdasarkan tabel 3 diketahui bahwa sebelum dilakukan intervensi therapy brain gym menunjukkan bahwa terdapat pengaruh setelah diberikan intervensi therapy brain gym pada anak usia sekolah di SDLBN 05 Kota Bengkulu.

Bermain bagi anak usia sekolah sangatlah penting, dengan bermain maka proses belajar akan efektif dan lebih cepat ditangkap pada saat mereka bermain serta salah satu manfaat dari bermain baik untuk pengembangan kognitif anak. Brain gym merupakan salah satu terapi bermain dengan kumpulan gerakan yang sederhana yang berfungsi untuk merangsang perkembangan seluruh bagian otak secara sinergis. Gerakan-gerakan dalam senam otak memiliki manfaat seperti menyeimbangkan otak, baik otak kanan maupun otak kiri, sehingga logika dan kreativitas anak menjadi seimbang, dapat membangun semangat dalam belajar berkonsentrasi, serta berpengaruh positif terhadap peningkatan perkembangan motorik, dan pengalihan emosi anak (Aprilasari, 2017).

Selain itu menurut Sari et al., (2018) senam otak/brain gym dapat merangsang perkembangan seluruh bagian otak, baik otak kanan, otak kiri, otak depan, maupun otak belakang secara sinergis. Disamping itu dari hasil penelitian Robot et al., (2019) hasil uji wilcoxon testnya menunjukkan terjadi peningkatan kesegaran jasmani sebesar $72,79 \%$ pada kelompok Perlakuan sebesar $74,86 \%$ pada Kelompok Kontrol. Sejalan juga dengan penelitian (Prasetyo \& Saputra, 2017). Diperjelas oleh penelitian Setyanti et al., (2019) bahwasanya senam otak juga mampu meningkatkan motorik halus pada anak retardasi mental.

\section{SIMPULAN}

Terdapat pengaruh therapy brain gym terhadap peningkatan short memory anak usia sekolah di SDLBN 05 Kota Bengkulu.

\section{SARAN}

Diharapkan pada penelitian selanjutnya untuk memberikan terapi kombinasi selain brain gym guna meningkatkan memory / daya ingat jangka panjang pada anak berkebutuhan khusus lainnya yang mengalami gangguan daya ingat.

\section{DAFTAR PUSTAKA}

Akbarjono, A., Willyandari, I., \& Saputra, A. (2019). Senam Otak (Brain Gym) Meningkatkan Memori Jangka Pendek (Short Memory) pada Anak Tuna Grahita Ringan Usia 8-9 Tahun. Internasional Seminar on Islamic Studies, 94-108. http://repository.iainbengkulu.ac.id/2941/

Aprilasari, M. S. (2017). Penerapan Aktivitas Brain Gym untuk Meningkatkan Perkembangan Anak Usia 4-6 Tahun di TK Marsudi Putro Yogyakarta [Universitas Jenderal Achmad Yani]. http://repository.unjaya.ac.id/id/eprint/2110 
Dewi, V. K. (2017). Hubungan Pola Asuh Orang Tua dengan Tingkat Kemandirian Anak Retardasi Mental Ringan. An-Nadaa, 1(1), 21-25. https://ojs.uniskabjm.ac.id/index.php/ANN/article/view/1015

Diana, S., Mafticha, E., \& Adiesti, F. (2017). Senam Otak Meningkatkan Prestasi Belajar Anak Usia Sekolah. E-Journal Keperawatan (e-Kp), 9(3), 144-147. http://journal.poltekkesdepkes-sby.ac.id/index.php/KEP/article/view/329

Dinas Kesehatan Provinsi Bengkulu. (2019). Profil Kesehatan Provinsi Bengkulu

Marpaung, D. R., Zulaini, Z., \& Alfonsus, Y. (2017). Pengaruh Pemberian Senam Otak terhadap Memori Jangka Pendek pada Mahasiswa Ikor FIK Unimed. Sains Olahraga: Jurnal Ilmiah Ilmu Keolahragaan, 1(1), 21-29. https://doi.org/10.24114/so.v1i1.6167

Martini, A., Fitriangga, A., \& Fahdi, F. K. (2016). Pengaruh Senam Otak terhadap Perubahan Daya Ingat (Fungsi Kognitif) pada Lansia di Panti Sosial Tresna Werdha Mulia Dharma Kubu Raya. Jurnal Keperawatan, 2002(1), 35-40. http://waset.org/publications/14223/soil-resistivity-data-computations-single-and-twolayer-soil-resistivity-structure-and-its--design\%0Ahttp://www.jo-mo.com/fadoohelp /data/DotNet/Ethical securty.pdf\%0Ahttp://link.springer.com/10.10

Padila, P., Andari, F. N., \& Andri, J. (2019). Hasil Skrining Perkembangan Anak Usia Toddler antara DDST dengan SDIDTK. Jurnal Keperawatan Silampari, 3(1), 244256. https://doi.org/10.31539/jks.v3i1.809

Padila, P., Harsismanto, J., Andrianto, M, B., Sartika, A., \& Ningrum, D. (2021). Pengalaman Orangtua dalam Merawat Anak Retardasi Mental. Jurnal Kesmas Asclepius, 3(1), 9-16. https://doi.org/https://doi.org/10.31539/jka.v3i1.2163

Panzilion, P., Padila, P., Tria, G., Amin, M., \& Andri, J. (2020). Perkembangan Motorik Prasekolah antara Intervensi Brain Gym dengan Puzzle. Jurnal Keperawatan Silampari, 3(2), 510-519. https://doi.org/10.31539/jks.v3i2.1120

Panzilion, P., Padila, P., \& Andri, J. (2021). Intervention of Numbers Puzzle Against Short Memory Mental Retardated Children. JOSING: Journal of Nursing and Health, 1(2), 41-47. https://doi.org/https://doi.org/10.31539/josing.v1i2.2332

Panzilion, P., Padila, P., Setyawati, A, D., Harsismanto, J., \& Sartika, A. (2020). Stimulation of Preschool Motor Development Through Brain Gym and Puzzle. JOSING: Journal of Nursing and Health, l(1), 10-17. https://doi.org/https://doi.org/10.31539/josing.v1i1.1166

Prasetyo, W., \& Saputra, S. A. (2017). Pengaruh Senam Otak terhadap Daya Ingat Anak Kelas V Sekolah Dasar. Jurnal Keperawatan, 6(1), 36-40. https://doi.org/10.47560/kep.v6i1.157

Pratiwi, S. E., Handoko, W., \& Rahmatania, R. (2016). Pengaruh Senam Otak terhadap Memori Jangka Pendek Mahasiswa. Jurnal Vokasi Kesehatan, II(1), 1-9. http://ejournal.poltekkes-pontianak.ac.id/index.php/JVK/article/view/47

Riskesdas. (2018). Hasil Utama Riset Kesehatan Dasar. Kementrian Kesehatan Republik Indonesia, 1-100. https://doi.org/https://doi.org/10.1088/1751-8113/44/8/085201

Robot, J. I., Adiputra, I. N., Lesmana, S. I., Sutjana, D. P., Griadhi, I. P. A., \& Imron, M. A. (2019). Penambahan Senam Otak pada Program Senam Sehat Anak Indonesia (SSAI) dapat Meningkatkan Memori Jangka Pendek dan Indeks Kesegaran Jasmani Siswa SD Inpres Pondang. Sport and Fitness Journal, 7(1), 10-19. https://doi.org/10.24843/spj.2019.v07.i01.p02 
Sari, L. P., Wahyuni, T. D., \& Putri, R. M. (2018). Pengaruh Senam Otak terhadap Peningkatan Motorik Halus pada Anak Usia 3-4 Tahun di Paud Mawar Tlogomas Malang. Nursing News, 3(1), 758-765. https://publikasi.unitri.ac.id/index.php/fikes/article/view/794

Setyanti, P. R. V., Suerni, T., \& Kandar, K. (2019). Efektivitas Senam Otak melalui Gerakan Arm Activation dan Terapi Kolase terhadap Motorik Halus pada Anak Retardasi Mental. Jurnal Keperawatan Jiwa, 6(1), 46. https://doi.org/10.26714/jkj.6.1.2018.4652

World Health Organization. (2019). Fact Sheet: Mental disorders. WHO. http://www.who.int/mediacentre/factsheets/fs396/en

Wulansari, A. P. (2018). Pengaruh Senam Otak (Brain Gym) terhadap Memori Jangka Pendek Mahasiswa Tingkat Akhir Fakultas Kedokteran Universitas Jenderal Achmad Yani [Universitas Jenderal Achmad Yani]. http://103.55.216.56/index.php/alasma/article/viewFile/17245 